\title{
ANTISPERMATOGENIC PROPERTIES OF BULL SEMINAL RIBONUCLEASE
}

\author{
E. LEONE, L. GRECO, R. K. RASTOGI AND L. IELA \\ Laboratorio di Chimica Biologica e II Cattedra di Anatomia Comparata, \\ Facoltd di Scienze, Universitd di Napoli, Napoli, Italy
}

(Received 11th April 1973)

Subcutaneous or intratesticular injection of guinea-pigs and rabbits with bovine seminal vesicle (BSV) secretion was shown by Matoušek (1969) to result in damage to the seminiferous epithelium. Recently, Dostál \& Matoušek (1972) obtained a purified protein from BSV secretion, with similar antispermatogenic properties. This protein had a molecular weight between 22,000 and 44,000 and was considered to be pure by several criteria, including chromatography, gel electrophoresis and immunoelectrophoresis.

There appeared to be a close similarity in physico-chemical properties between the antispermatogenic protein of Dostál \& Matoušek (1972) and the ribonuclease (RNAase BS-1) which was discovered in bull seminal plasma in 1963 in one of our laboratories and was subsequently obtained in a crystalline state (D'Alessio \& Leone, 1963; Floridi \& D'Alessio, 1967; Floridi, 1968); the details concerning the physico-chemical and catalytic properties of this enzyme were described by D'Alessio, Floridi, De Prisco, Pignero \& Leone (1972) and Floridi, D'Alessio \& Leone (1972). The enzyme was shown to consist of two similar sub-units (D'Alessio, Parente, Guida \& Leone, 1972), and its amino acid sequence has been determined (Leone, Suzuki, Greco, Parente, Farina \& La Montagna, 1972). We have also shown that RNAase BS-1 originates in the seminal vesicles (Farina \& Leone, 1968; Farina, De Prisco \& Leone, 1971).

To find whether our RNAase BS-1 is in fact identical with the protein credited by Dostál \& Matoušek with antispermatogenic properties, we carried out the following study.

Using $36.5 \mathrm{ml}$ of freshly collected BSV secretion, the antispermatogenic protein was purified by the method described by Dostál \& Matoušek (1972) and each purified fraction was tested for RNAase activity. The final product of purification was endowed with high RNAase activity (Table 1), comparable to that of pure RNAase BS-1 prepared by our method (D'Alessio, Floridi, De Prisco, Pignero \& Leone, 1972). The identity of the product with RNAase BS-1 was confirmed by (i) polyacrylamide gel electrophoresis at $\mathrm{pH} 5.5$ which revealed that both substances, tested either singly or in mixture, had the same electrophoretic mobility and produced an identical single band, (ii) amino acid analysis which showed that the percentage composition of amino acids was the same, (iii) analysis of the u.v. spectrum and absorption coefficient, which showed that the purified antispermatogenic protein, dissolved in 10 mM-sodium phosphate, $\mathrm{pH} 7.0$, exhibited the same maximum absorbance at $277.5 \mathrm{~nm}$ as our RNAase BS-1, and (iv) determination of molecular weight 
(gel filtration on calibrated columns of Sephadex G-75) which gave values in the range of 28,000 to 30,000 for both proteins.

We also gave unilateral intratesticular injections of either 100 or $200 \mu \mathrm{g}$ RNAase BS-1 (prepared by our method) to a group of mice and examined both testes of each animal 10 days later. The injected testes were abnormally small, and the seminiferous tubules were of much reduced diameter and showed varying degrees of histological damage (Table 2 and Pl. 1, Figs 1 and

Table 1. RNAase activity of aspermatogenic substance*

\begin{tabular}{l|c|c|c}
\hline & $\begin{array}{c}\text { Total protein } \\
(\mathrm{mg})\end{array}$ & $\begin{array}{c}\text { Total RNAase activity } \\
(\text { Kunitz units })\end{array}$ & $\begin{array}{c}\text { RNAase units/mg protein } \\
\text { (specific activity) }\end{array}$ \\
\hline $\begin{array}{l}\text { Starting material } \\
\quad \text { (vesicular secretion) }\end{array}$ & 4780 & 2190 & 0.46 \\
$\begin{array}{l}\text { Supernatant from the acetic acid } \\
\text { precipitate }\end{array}$ & 3402 & 1780 & 0.52 \\
$\begin{array}{l}\text { Supernatant from the ammonium } \\
\text { sulphate precipitate }\end{array}$ & 54 & 960 & 17.0 \\
Eluate from GM-Sephadex column & 24 & 960 & 40.0 \\
Eluate from Sephadex G-100 column & 20 & 868 & 43.0 \\
\hline
\end{tabular}

* Prepared by the method described by Dostál \& Matoušek (1972).

2). At the higher dose level, there was complete disappearance of spermatogenic and Leydig cells. Of ten control animals injected with saline, seven showed no alterations in the testes but in three, there were some alterations.

Identical results were obtained when either BSV secretion or RNAase SV-1, a ribonuclease purified from the glands, similar to RNAase BS-1 (Leone, Parente, Farina \& De Prisco, 1973) was injected. In the latter experiment, histological damage was also noted in the contralateral testes (Table 2), presumably due to dispersion of material through the systemic circulation.

Essentially similar results were obtained when mice were injected subcutaneously with $0.5 \mathrm{mg}$ RNAase BS-1 dissolved in $0.9 \% \mathrm{NaCl}$; the injections were made daily for 3 or 5 days; a group of control animals received injections of $0.9 \% \mathrm{NaCl}$.

When preparing our paper, we read a paper by Holý \& Grozdanovič (1972) in which reference was made to Matoušek (1969) as an author who also attributed the antispermatogenic properties of BSV secretion to RNAase. We failed, however, to find that information in the paper by Matoušek (1969). Finally, we conclude that the antispermatogenic substance is in fact, identical with RNAase BS-1.

\section{EXPLANATION OF PLATE 1}

FIG. 1. Mouse testis injected with $100 \mu \mathrm{g}$ RNAase BS-1. The majority of the tubules are reduced in diameter and contain nothing but spermatogonia and occasionally some primary spermatocytes. The Leydig cells show atrophy. $\times 160$.

FIg. 2. Mouse testis injected with $200 \mu \mathrm{g}$ RNAase BS-1 showing atrophic tubules and total loss of Leydig cells. Some tubules contain only spermatogonia and spermatocytes while others show total disappearance of spermatogenic elements (arrows). The intertubular spaces are occupied by connective tissue only. $\times 240$. 
PLATE 1

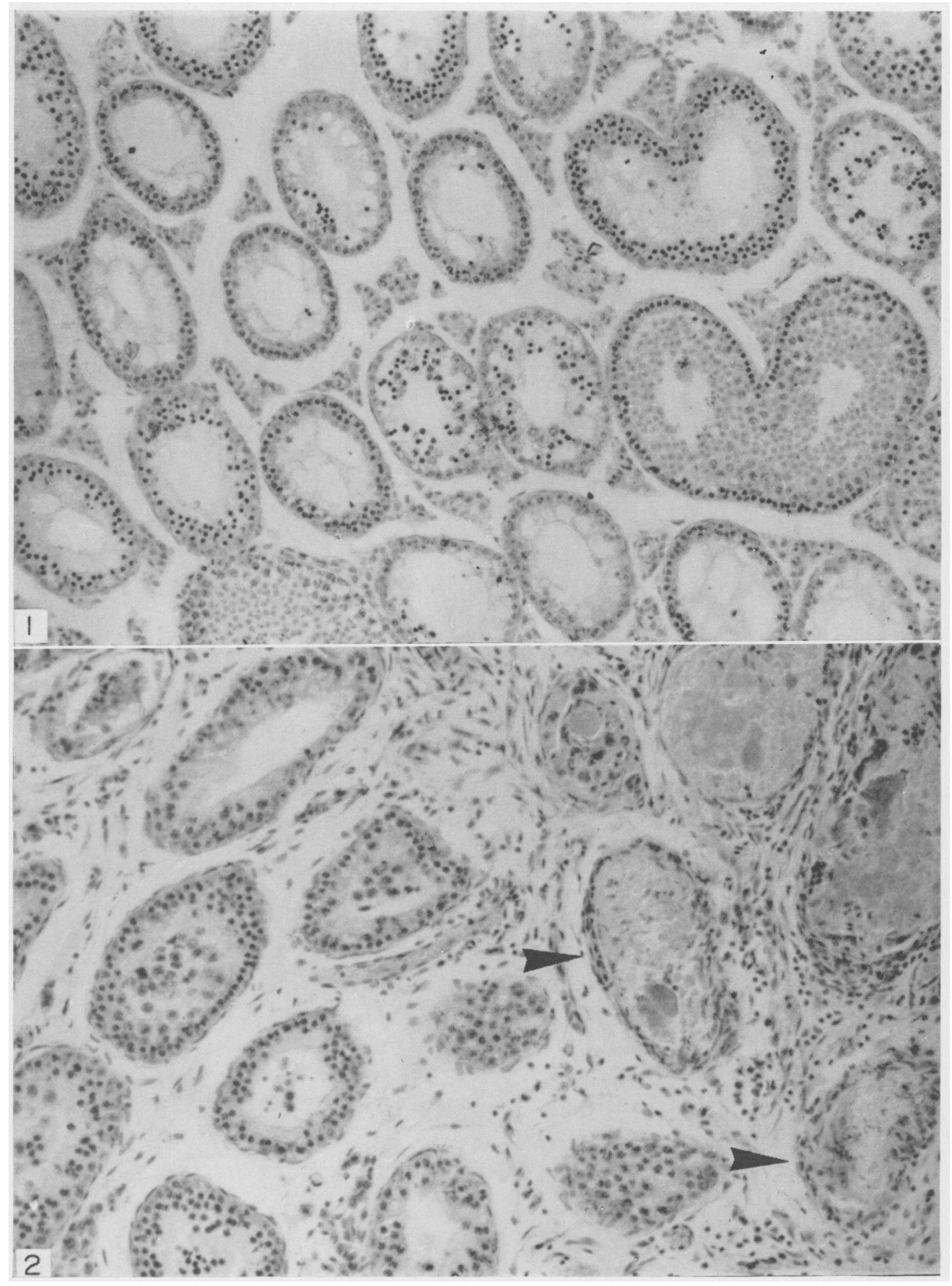

(Facing p. 198) 
Antispermatogenic properties of ribonuclease

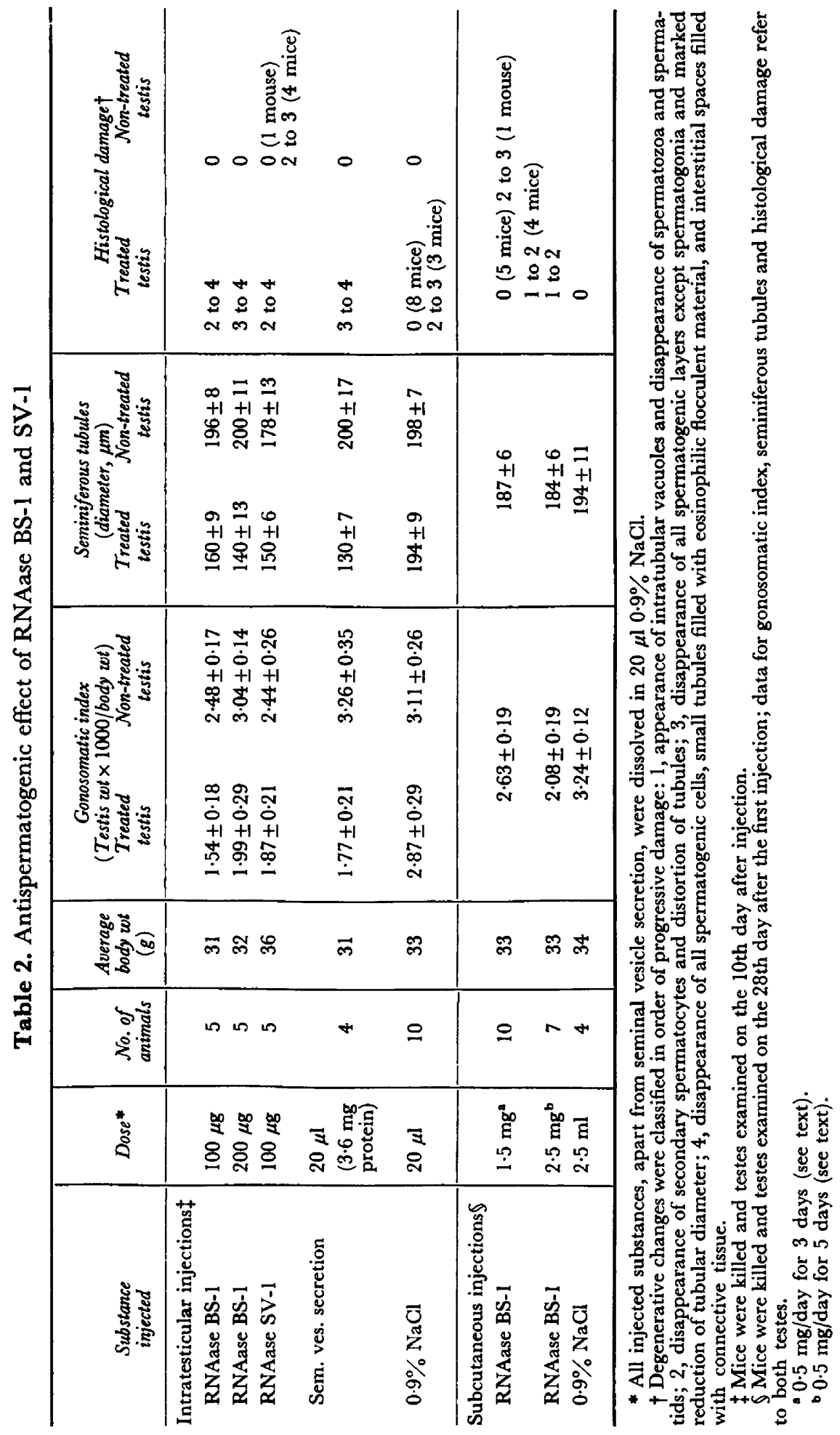


We would like to thank Professor G. Chieffi for helpful discussion, and $\mathrm{Dr}$ R. De Prisco for preparing RNAase BS-1 for us. This work has been partly supported by Consiglio Nazionale delle Ricerche, Contract 71.01907.04.

\section{REFERENGES}

D’Alessio, G., Floridi, A., De Prisco, R., Pignero, A. \& Leone, E. (1972) Bull semen ribonucleases. 1. Purification and physico-chemical properties of the major component. Eur. Fnl Biochem. 26, 153.

D'Alessio, G. \& Leone, E. (1963) The action of seminal enzymes on ribonucleic acid. Biochem. 7 . 89, $7 \mathbf{P}$.

D'Alessio, G., Parente, A., Guida, G. \& Leone, E. (1972) Dimeric structure of seminal ribonuclease. FEBS Lett. 27, 285.

Dostál, J. \& Matouš́, J. (1972) Purification of aspermatogenic substance in bull seminal vesicle fluid. 7. Reprod. Fert. 31, 273.

Farina, B., De Prisco, R. \& Leone, E. (1971) Origine delle RNAasi seminali. Boll. Soc. ital. Biol. sper. 47, Abstr. No. 96.

Farina, B. \& Leone, E. (1968) Enzimi del plasma seminale di toro:studio di gele-lettroforesi. Boll. Soc. ital. Biol. sper. 44, 159.

Floridi, A. (1968) Grystalline ribonuclease from bull semen. Biochem. biophys. Res. Commun. $32,179$.

Florid, A. \& D'Alessio, G. (1967) Comportamento cromatografico della ribonucleasi seminale. Boll. Soc. ital. Biol. sper. 43, 32.

Floridi, A., D'Alessio, G. \& Leone, E. (1972) Bull semen ribonucleases. 2. Catalytic properties of the major component. Eur. Fnl Biochem. 26, 162.

Holý, A. \& Grozdanovič, J. (1972) The substrate specificity of bovine seminal vesicle fluid ribonuclease (ribonuclease AS). Biochim. biophys. Acta, 277, 556.

Leone, E., Parente, A., Farina, B. \& De Prisco, R. (1973) Ribonucleases from bull seminal vesicles. In: 9th Int. Congr. Biochem., Stockholm (in press).

Leone, E., Suzuki, H., Greco, L., Parente, A., Farina, B. \& La Montagna, R. (1972) Sequence of seminal ribonuclease (RNAase BS-1). In: 8th Meeting of Federation of European Biochemical Societies, Amsterdam, Abstr. No. 359.

MAtoušEK, J. (1969) Effects on spermatogenesis in guinea-pigs, rabbits and sheep after their immunization with sexual organ fluids of bulls. J. Reprod. Fert. 19, 63. 